\title{
Paenibacillus sacheonensis sp. nov., a xylanolytic and cellulolytic bacterium isolated from tidal flat sediment
}

Correspondence

Sang Yeol Lee

sylee@gnu.ac.kr
Jeong Chan Moon, ${ }^{1}$ Young Jun Jung, ${ }^{1}$ Ji Hyun Jung, ${ }^{1}$ Hyun Suk Jung, ${ }^{2}$ Young Ryun Cheong, ${ }^{1}$ Che Ok Jeon, ${ }^{3}$ Kyun Oh Lee ${ }^{1}$ and Sang Yeol Lee ${ }^{1}$

\author{
${ }^{1}$ Division of Applied Life Science (BK 21), PMBBRC, Gyeongsang National University, \\ Jinju 660-701, Republic of Korea \\ ${ }^{2}$ Division of Electron Microscopic Research, Korea Basic Science Institute, 52 Eoeun-dong, \\ Daejeon 305-333, Republic of Korea \\ ${ }^{3}$ Department of Life Science, Chung-Ang University, Seoul 156-756, Republic of Korea
}

Xylan is a heterogeneous and abundant polymer composed of $(1,4)$-linked $\beta$-D-xylosyl residues. It is the major component of the hemicelluloses of monocotyledon cell walls (Timell, 1967). Xylanases (1,4- $\beta$-D-xylanohydrolases) are a group of xylanolytic enzymes that hydrolyse xylan to xylan oligosaccharides and xylose. Several bacterial and fungal species produce the full complement of enzymes necessary to utilize xylan as a carbon source (Uffen, 1997). The genus Paenibacillus contains several species that are able to hydrolyse xylan (Akaracharanya et al., 2009; Aÿ et al., 1998; Beneduzi et al., 2010; Hespell, 1996; Khianngam et al., 2009a, b; Lee et al., 2000; Lee \& Yoon, 2008; Morales et al., 1995; Nelson et al., 2009; Nielsen \& Sorensen, 1997; Park et al., 2007, 2009; Rivas et al., 2005a, b, 2006; Sánchez et al., 2005; Ten et al., 2006; Velázquez et al., 2004; Valverde et al., 2010; Yoon et al., 2002; Zamost et al., 1991). At the time of writing, the genus Paenibacillus, which was originally

\footnotetext{
Abbreviations: ML, maximum-likelihood; MP, maximum-parsimony; NJ, neighbour-joining.

The GenBank/EMBL/DDBJ accession number for the $16 \mathrm{~S}$ rRNA gene sequence of strain $\mathrm{SYO}^{\top}$ is GU124597.

Supplementary figures are available with the online version of this paper.
}

proposed by Ash et al. (1993), contained 118 species with validly published names. Generally, members of this genus are facultatively anaerobic or strictly aerobic, rod-shaped bacteria that produce spores in swollen sporangia and have DNA G + C contents of 45-57 mol\% (Ash et al., 1993). In this paper, the isolation and classification of a novel species of the genus Paenibacillus is described.

A novel bacterium, designated strain $\mathrm{SY}^{\mathrm{T}}{ }^{\mathrm{T}}$, was isolated from tidal flat sediment from Sacheon Bay, South Korea. The sediment sample was serially diluted with sterile water, spread on half-strength tryptic soy broth (TSB) agar (Difco) and incubated at $30{ }^{\circ} \mathrm{C}$. Strain $\mathrm{SYO}^{\mathrm{T}}$ was isolated after 7 days of incubation and cryopreserved at $-80{ }^{\circ} \mathrm{C}$ in 10 fold-diluted TSB supplemented with $20 \%(\mathrm{v} / \mathrm{v})$ glycerol. Cultures were maintained in 10-fold-diluted TSB agar.

Strain $\mathrm{SY}^{\mathrm{T}} 1^{\mathrm{T}}$ was cultivated for 2 days at $30{ }^{\circ} \mathrm{C}$ in 10 -folddiluted TSB medium to determine the cell morphology by using a Zeiss light microscope at $\times 1000$ magnification. The presence of flagella was investigated using a transmission electron microscope (Tecnai G2 Spirit Twin; FEI). TEM images with scale bars were used to determine the cell size. Growth at 4, 10, 20, 28, 37, 40 and $50{ }^{\circ} \mathrm{C}$ and $\mathrm{pH}$ 5, 6, 7, 8, 9, 10 and 11 was tested on 10 -fold-diluted TSB medium after 
7 days of incubation. The $\mathrm{pH}$ of the TSB was adjusted by adding $1 \mathrm{M} \mathrm{NaOH}$ or $1 \mathrm{M} \mathrm{HCl}$. Salt tolerance was tested in 10-fold-diluted TSB supplemented with $0-5.0 \%(\mathrm{w} / \mathrm{v}) \mathrm{NaCl}$ at $1 \%$ intervals after 7 days of incubation at $30{ }^{\circ} \mathrm{C}$. For antibiotic susceptibility testing of the strain, the following antibiotic discs (Oxoid) were placed on 10-fold-diluted TSB agar plates spread with strain $\mathrm{SY}^{\mathrm{T}} 1^{\mathrm{T}}$ : kanamycin $(30 \mu \mathrm{g})$, streptomycin $(10 \mu \mathrm{g})$, vancomycin $(30 \mu \mathrm{g})$, gentamicin $(10 \mu \mathrm{g})$, penicillin $\mathrm{G}(10 \mathrm{U})$, erythromycin $(15 \mu \mathrm{g})$, ampicillin $(10 \mu \mathrm{g})$, chloramphenicol $(30 \mu \mathrm{g})$, tetracycline $(30 \mu \mathrm{g})$ and piperacillin/tazobactam 10:1 (110 $\mu \mathrm{g})$.

Gram staining was carried out by using bioMérieux Gram staining kit according to the manufacturer's instructions. Spore formation was determined by staining with malachite green. Strain $\mathrm{SY}_{0} 1^{\mathrm{T}}$ was grown in 10-fold-diluted TSB for $48 \mathrm{~h}$ at $30{ }^{\circ} \mathrm{C}$ for menaquinone analyses and genomic DNA isolation. Isoprenoid quinones and the $\mathrm{G}+\mathrm{C}$ content of the genomic DNA were analysed using reversed-phase HPLC according to the methods described by Komagata \& Suzuki (1987) and Mesbah et al. (1989), respectively. For examination of the fatty acid composition, strain SY01 ${ }^{\mathrm{T}}$ was grown on 10 -fold-diluted TSB agar at $30{ }^{\circ} \mathrm{C}$ for $48 \mathrm{~h}$ until the late exponential phase of growth. The analysis of fatty acid methyl esters was performed according to the instructions of the Microbial Identification System (MIDI; Microbial ID). Polar lipid analyses were carried out by the Identification Service of the DSMZ and Dr B. J. Tindall (DSMZ, Braunschweig, Germany). Hydrolysis of casein, xylan, aesculin, gelatin, carboxymethylcellulose (CMC), starch, tyrosine, urea, Tween 20 and Tween 80 was tested as described by Lányí (1987) and Smibert \& Krieg (1994).

Physiological and biochemical properties and enzyme activities were analysed using API 20NE, API 20E and API $50 \mathrm{CH}$ strips combined with API $50 \mathrm{CHB} / \mathrm{E}$ medium, according to the manufacturer's instructions (bioMérieux). Oxidase activity was determined using $1 \%(\mathrm{w} / \mathrm{v}) N, N, N^{\prime}, N^{\prime}-$ tetramethyl-p-phenylenediamine dihydrochloride (T3134; Sigma-Aldrich) and catalase activity was tested by the production of oxygen bubbles in $3 \%(\mathrm{v} / \mathrm{v})$ aqueous hydrogen peroxide solution. The phenotypic characteristics of Paenibacillus phyllosphaerae PALXIL04 ${ }^{\mathrm{T}}$, the closest neighbour of strain $\mathrm{SY} 01^{\mathrm{T}}$ according to $16 \mathrm{~S}$ rRNA gene sequences, differed from those of strain $\mathrm{SYO}^{\mathrm{T}}$ as regards nitrate reduction, catalase activity and carbon source utilization (Table 1). Strain $\mathrm{SY} 1^{\mathrm{T}}$ was Gram-negative-staining, catalase-negative and oxidase-positive. Strain $\mathrm{SY}_{01}{ }^{\mathrm{T}}$ did not reduce nitrate to nitrite. Differential characteristics between strain $\mathrm{SY} 1^{\mathrm{T}}$ and closely related species of the genus Paenibacillus are shown in Table 1.

For 16S rRNA gene sequencing, extraction of genomic DNA was carried out using a commercial genomic DNA extraction kit (GeneAll). Amplification of the 16S rRNA gene was performed using the universal primers $27 \mathrm{~F}\left(5^{\prime}\right.$ AGAGTTTGATCMTGGCTCAG-3') and 1492R (5'-GGTTACCTTGTTACGACTT-3') (Lane, 1991). The PCR products were sequenced by Invitrogen Corporation,
Table 1. Distinctive characteristics of strain $S Y 01^{\top}$ and closely related species of the genus Paenibacillus

Strains: $1, \mathrm{SY}^{\mathrm{T}}{ }^{\mathrm{T}} ; 2$, P. phyllosphaerae PALXIL04 ${ }^{\mathrm{T}} ; 3$, P. tarimensis SA-7-6 ${ }^{\mathrm{T}}$; 4, P. mendelii C $/ 2^{\mathrm{T}} ; 5$, P. kobensis DSM $10249^{\mathrm{T}} ; 6$, P. humicus $\mathrm{PC}-147^{\mathrm{T}}$. All data are from this study unless indicated otherwise. + , Positive; -, negative; $\mathrm{w}$, weakly positive.

\begin{tabular}{|c|c|c|c|c|c|c|}
\hline Characteristic & 1 & 2 & 3 & 4 & 5 & 6 \\
\hline Gram stain & - & $-*$ & $-{ }^{*}$ & $-{ }^{*}$ & + & - \\
\hline Oxidase & + & + & $t^{*}$ & + & - & + \\
\hline Catalase & - & + & + & + & + & + \\
\hline Nitrate reduction & - & + & - & - & $-{ }^{\star}$ & - \\
\hline $\begin{array}{l}\text { DNA G }+ \text { C content } \\
(\mathrm{mol} \%) \dagger\end{array}$ & 56.1 & $50.7^{\mathrm{a}}$ & $53.7^{b}$ & $50.8^{c}$ & $50-52^{d}$ & $58^{e}$ \\
\hline \multicolumn{7}{|l|}{ Hydrolysis of: } \\
\hline Xylan & + & + & + & - & - & + \\
\hline Casein & - & $\mathrm{W}$ & + & - & - & + \\
\hline $\mathrm{CMC}$ & + & + & + & - & - & + \\
\hline \multicolumn{7}{|l|}{ Utilization of: } \\
\hline Glycerol & $\mathrm{w}$ & $\mathrm{W}$ & - & + & $\mathrm{W}$ & - \\
\hline D-Ribose & $\mathrm{w}$ & - & - & + & + & - \\
\hline D-Xylose & w & + & + & + & - & - \\
\hline $\begin{array}{l}\text { Methyl } \beta \text {-D- } \\
\text { xylopyranoside }\end{array}$ & - & $+^{*}$ & $\mathrm{~W}$ & + & - & - \\
\hline D-Glucose & + & + & + & + & + & $+^{*}$ \\
\hline D-Fructose & + & + & - & + & + & - \\
\hline D-Mannose & - & $-{ }^{*}$ & + & - & + & - \\
\hline L-Rhamnose & - & + & - & + & - & - \\
\hline D-Mannitol & + & + & $-{ }^{*}$ & - & - & $+^{*}$ \\
\hline$N$-Acetylglucosamine & w & $+^{*}$ & - & - & + & $\mathrm{W}$ \\
\hline Amygdalin & - & + & $\mathrm{w}$ & - & $\mathrm{w}$ & + \\
\hline Arbutin & - & + & - & - & + & - \\
\hline Salicin & - & + & + & + & + & - \\
\hline Melezitose & + & - & - & + & - & $+^{*}$ \\
\hline Gluconate & - & - & - & - & + & - \\
\hline 5-Ketogluconate & - & - & - & + & - & - \\
\hline
\end{tabular}

${ }^{\star}$ Results different from those in the studies by Rivas et al. (2005a), Wang et al. (2008), Šmerda et al. (2005), Kanzawa et al. (1995) and Vaz-Moreira et al. (2007).

$\dagger$ Data from other studies indicated as follows: a, Rivas et al. (2005a); b, Wang et al. (2008); c, Šmerda et al. (2005); d, Kanzawa et al. (1995); e, Vaz-Moreira et al. (2007).

where a $1405 \mathrm{bp}$ fragment was obtained. Identification of phylogenetic neighbours and calculation of pairwise $16 \mathrm{~S}$ rRNA gene sequence similarity were carried out by using the EzTaxon server (http://www.eztaxon.org/; Chun et al., 2007). Phylogenetic trees were constructed by using three different methods, the neighbour-joining (NJ), maximumlikelihood (ML) and maximum-parsimony (MP) algorithms (Thompson et al., 1994). The ML and MP programs were available in PHYLIP software, version 3.6 (Felsenstein, 2002), while the NJ algorithm was taken from the MEGA4 package (Tamura et al., 2007). Evolutionary distance matrices were calculated using Kimura's two-parameter model (Kimura, 1980) for the NJ method. Phylogenetic 
analysis based on the 16S rRNA gene sequences indicated that the strain $\mathrm{SY}_{01}{ }^{\mathrm{T}}$ formed a distinct phyletic lineage within the genus Paenibacillus (Fig. 1). The topologies of phylogenetic trees based on the ML and MP algorithms also supported the result of the NJ tree (Saiton \& Nei, 1987) and confirmed that strain SY01 $1^{\mathrm{T}}$ represented a novel member of the genus Paenibacillus (see Supplementary Figs S1 and S2 in IJSEM Online).

16S rRNA gene sequence comparisons showed that strain $S Y 01^{\mathrm{T}}$ was most closely related to $P$. phyllosphaerae PALXIL04 $^{\mathrm{T}}(95.9 \%)$, Paenibacillus tarimensis SA-7 $-6^{\mathrm{T}}$ (94.6\%) and Paenibacillus mendelii $\mathrm{C} / 2^{\mathrm{T}}$ (94.4\%). Sequence similarities to the type strains of other members of the genus Paenibacillus were below $94.0 \%$. The predominant isoprenoid quinone detected in strain $\mathrm{SY}_{01}{ }^{\mathrm{T}}$ was MK-7. The major fatty acid of strain $\mathrm{SY}_{0} 1^{\mathrm{T}}$ was anteiso- $\mathrm{C}_{15: 0}$, which is the predominant cellular fatty acid found in the genus Paenibacillus (Table 2) (Shida et al., 1997a, b). The level of fatty acid anteiso- $\mathrm{C}_{15: 0}$ in strain $\mathrm{SY} 01^{\mathrm{T}}$ was higher than that found for other type strains of the genus. Strain $\mathrm{SY}_{01}{ }^{\mathrm{T}}$ showed higher levels of iso- $C_{15: 0}$ but lower levels of $\mathrm{C}_{16: 0}$ when compared with $P$. phyllosphaerae PALXIL04 ${ }^{\mathrm{T}}$. The major polar lipids present were diphosphatidylglycerol, phosphatidylglycerol, phosphatidylethanolamine, four unknown aminophospholipids, five unknown phospholipids and an unknown phosphoglycolipid. The DNA G+C content of strain $\mathrm{SY}^{\mathrm{T}}{ }^{\mathrm{T}}$ was $56.1 \mathrm{~mol} \%$. This value was similar to that obtained from closely related species of the genus Paenibacillus.

On the basis of the phylogenetic, chemotaxonomic and physiological characteristics, strain $\mathrm{SY}^{\mathrm{T}}{ }^{\mathrm{T}}$ represents a novel species of the genus Paenibacillus, for which the name Paenibacillus sacheonensis sp. nov. is proposed.

\section{Description of Paenibacillus sacheonensis sp. nov.}

Paenibacillus sacheonensis (sa.che.o.nen'sis. N.L. masc. adj. sacheonensis of or belonging to Sacheon, the city in Korea where the type strain was isolated).

Cells are Gram-negative-staining, motile and rod-shaped (0.8-1.0 $\mu \mathrm{m}$ wide and 2.8-3.8 $\mu \mathrm{m}$ long) (see Supplementary Fig. S2 in IJSEM Online). A spherical endospore is formed at a central to subterminal position. After $48 \mathrm{~h}$ incubation at $30{ }^{\circ} \mathrm{C}$ on 10 -fold-diluted TSB agar plates, colonies are 1$2 \mathrm{~mm}$ in diameter, smooth, round, flat and translucent/ white. The temperature range for growth is $10-40{ }^{\circ} \mathrm{C}$ and the optimum temperature for growth is $30{ }^{\circ} \mathrm{C}$. The $\mathrm{pH}$ growth range is between 6.0 and 9.0, with an optimum at $\mathrm{pH}$ 7.0. Growth occurs in the absence of $\mathrm{NaCl}$ and no growth occurs in the presence of $>1.0 \%(\mathrm{w} / \mathrm{v}) \mathrm{NaCl}$ in 10 fold-diluted TSB medium. Xylan, aesculin, starch, gelatin and $\mathrm{CMC}$ are hydrolysed. Gives a positive result in tests for oxidase, but catalase is negative. Positive result in tests for $\beta$-galactosidase and acetoin production (weak), but negative result for arginine dihydrolase, lysine decarboxylase, ornithine decarboxylase, $\mathrm{H}_{2} \mathrm{~S}$ production, urease, tryptophan deaminase, indole production, glucose fermentation and nitrate reduction. No assimilation of caproate, adipate, citrate, phenylacetate or malate. Acid is produced from glycerol, L-arabinose, D-ribose, D-xylose, D-galactose, Dglucose, D-fructose, D-mannitol, $N$-acetylglucosamine, aesculin, cellobiose, maltose, lactose, melibiose, sucrose, trehalose, melezitose, raffinose, starch, glycogen, gentiobiose and turanose, but not from erythritol, D-arabinose, L-xylose, D-adonitol, methyl $\beta$-D-xylopyranoside, D-mannose, L-sorbose, L-rhamnose, dulcitol, inositol, D-sorbitol, methyl $\alpha$-D-mannopyranoside, methyl $\alpha$-D-glucopyranoside,

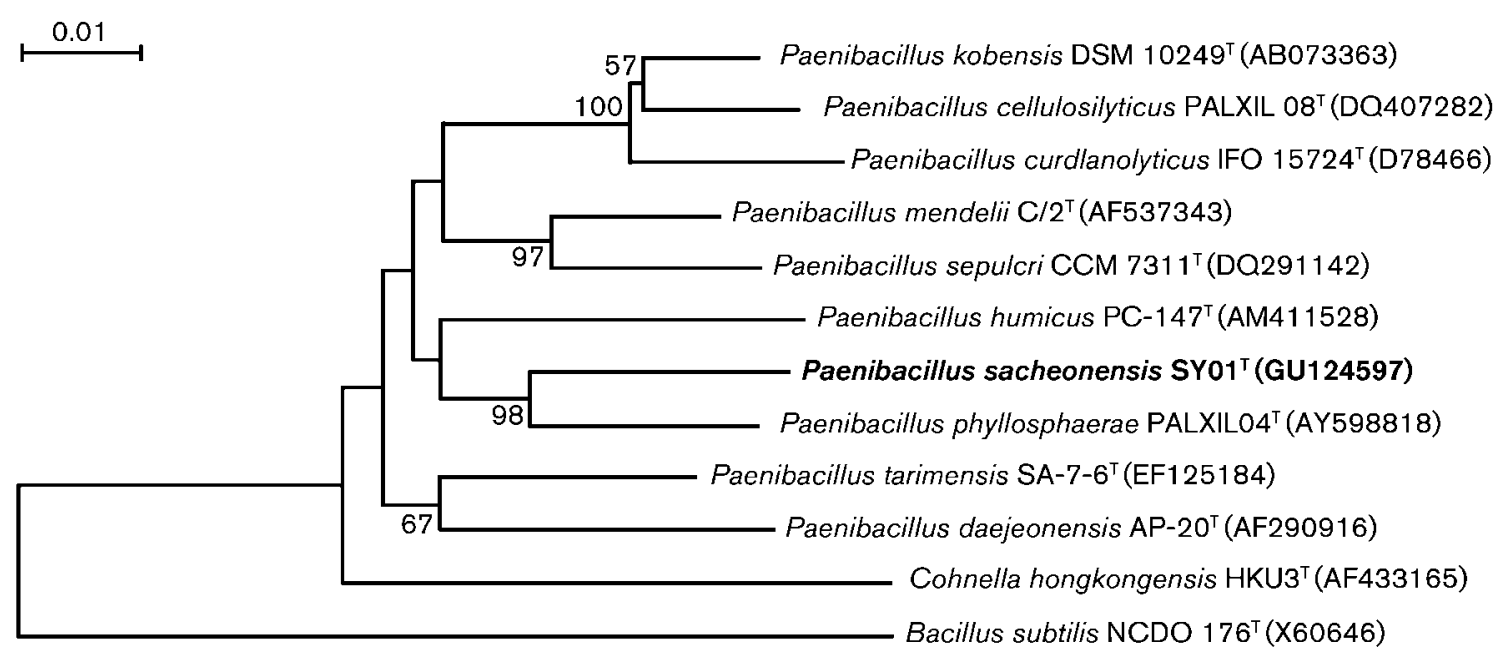

Fig. 1. The phylogenetic relationships of strain $\mathrm{SY}_{01}{ }^{\top}$ within the genus Paenibacillus determined using $16 \mathrm{~S}$ rRNA gene sequence analysis. The phylogenetic tree was constructed by using the NJ method and Kimura's two-parameter model as the substitution model. GenBank accession numbers are given in parentheses. Bootstrap values (expressed as percentage of 1000 replications) $>50 \%$ are shown at the branch points. Bar, 1 substitution per $100 \mathrm{nt}$. 
Table 2. Cellular fatty acid composition of strain $S Y 01^{\top}$ and phylogenetically related species of the genus Paenibacillus

Strains: $1, \mathrm{SY}^{\mathrm{T}} ; 2$, P. phyllosphaerae PALXIL04 ${ }^{\mathrm{T}} ; 3$, P. tarimensis SA-7-6 ${ }^{\mathrm{T}}$; 4, P. mendelii $\mathrm{C} / 2^{\mathrm{T}} ; 5$, P. kobensis DSM $10249^{\mathrm{T}} ; 6$, P. humicus $\mathrm{PC}-147^{\mathrm{T}}$. All data are from this study. ND, Not detected.

\begin{tabular}{|c|c|c|c|c|c|c|}
\hline Fatty acid & 1 & 2 & 3 & 4 & 5 & 6 \\
\hline \multicolumn{7}{|l|}{ Saturated fatty acids } \\
\hline $\mathrm{C}_{13: 0}$ & $\mathrm{ND}$ & $\mathrm{ND}$ & $\mathrm{ND}$ & 2.0 & $\mathrm{ND}$ & ND \\
\hline $\mathrm{C}_{14: 0}$ & $\mathrm{ND}$ & 2.9 & 1.1 & $\mathrm{ND}$ & 4.3 & 3.8 \\
\hline $\mathrm{C}_{15: 0}$ & 6.0 & 2.4 & 5.2 & 8.2 & ND & 4.7 \\
\hline $\mathrm{C}_{16: 0}$ & 3.1 & 22.3 & 7.8 & 8.6 & 26.2 & 4.7 \\
\hline $\mathrm{C}_{18: 0}$ & $\mathrm{ND}$ & 2.0 & 7.5 & $\mathrm{ND}$ & $\mathrm{ND}$ & 3.2 \\
\hline \multicolumn{7}{|l|}{ Branched fatty acids } \\
\hline iso- $\mathrm{C}_{14: 0}$ & 3.6 & 4.6 & $\mathrm{ND}$ & 5.0 & $\mathrm{ND}$ & 1.9 \\
\hline iso- $\mathrm{C}_{15: 0}$ & 18.9 & 5.1 & 8.1 & 6.2 & 3.5 & 7.1 \\
\hline anteiso- $\mathrm{C}_{15: 0}$ & 47.2 & 34.6 & 43.0 & 42.8 & 38.2 & 40.3 \\
\hline iso- $\mathrm{C}_{16: 0}$ & 10.5 & 10.9 & 3.7 & 16.1 & 8.2 & 11.5 \\
\hline iso- $\mathrm{C}_{16: 1} \mathrm{H}$ & $\mathrm{ND}$ & $\mathrm{ND}$ & 0.2 & ND & $\mathrm{ND}$ & 3.2 \\
\hline iso- $\mathrm{C}_{17: 0}$ & 4.0 & 1.9 & 2.1 & $\mathrm{ND}$ & $\mathrm{ND}$ & ND \\
\hline iso- $\mathrm{C}_{17: 0} 3-\mathrm{OH}$ & $\mathrm{ND}$ & $\mathrm{ND}$ & $\mathrm{ND}$ & $\mathrm{ND}$ & $\mathrm{ND}$ & 1.7 \\
\hline anteiso- $\mathrm{C}_{17: 0}$ & 4.0 & 6.7 & 14.5 & 5.2 & 5.6 & 9.7 \\
\hline iso- $\mathrm{C}_{18: 0}$ & $\mathrm{ND}$ & $\mathrm{ND}$ & 2.1 & $\mathrm{ND}$ & $\mathrm{ND}$ & ND \\
\hline iso- $\mathrm{C}_{20: 0}$ & $\mathrm{ND}$ & $\mathrm{ND}$ & ND & ND & ND & 0.7 \\
\hline \multicolumn{7}{|l|}{ Unsaturated } \\
\hline $\mathrm{C}_{14: 1} \omega 5 c$ & 2.7 & 5.2 & 0.9 & 5.9 & 5.2 & 7.5 \\
\hline $\mathrm{C}_{16: 1} \omega 7 c$ alcohol & $\mathrm{ND}$ & 1.4 & ND & ND & $\mathrm{ND}$ & ND \\
\hline $\mathrm{C}_{16: 1} \omega 9 c$ & $\mathrm{ND}$ & $\mathrm{ND}$ & $\mathrm{ND}$ & $\mathrm{ND}$ & 3.6 & ND \\
\hline $\mathrm{C}_{16: 1} \omega 11 c$ & $\mathrm{ND}$ & $\mathrm{ND}$ & 1.5 & ND & ND & ND \\
\hline $\mathrm{C}_{18: 1} \omega 9 c$ & $\mathrm{ND}$ & $\mathrm{ND}$ & $\mathrm{ND}$ & $\mathrm{ND}$ & 5.3 & ND \\
\hline Summed feature $4^{*}$ & $\mathrm{ND}$ & $\mathrm{ND}$ & 2.3 & $\mathrm{ND}$ & $\mathrm{ND}$ & ND \\
\hline
\end{tabular}

${ }^{*}$ Summed feature 4 represents iso- $\mathrm{C}_{17: 1} \mathrm{I}$ and/or anteiso- $\mathrm{C}_{17: 1} \mathrm{~B}$, which could not be separated by GLC using the MIDI system.

amygdalin, arbutin, salicin, inulin, xylitol, D-lyxose, Dtagatose, D-fucose, L-fucose, D-arabitol, gluconate, 2-ketogluconate or 5-ketogluconate. Sensitive to kanamycin, streptomycin, vancomycin, gentamicin, penicillin G, erythromycin, ampicillin, chloramphenicol, tetracycline and piperacillin/tazobactam $10: 1$. The main cellular fatty acids are anteiso- $\mathrm{C}_{15: 0}(47.2 \%)$, iso- $\mathrm{C}_{15: 0}(18.9 \%)$, iso- $\mathrm{C}_{16: 0}$ $(10.5 \%)$. The major polar lipids present are diphosphatidylglycerol, phosphatidylglycerol, phosphatidylethanolamine, four unknown aminophospholipids, five unknown phospholipids and an unknown phosphoglycolipid. The predominant menaquinone is MK-7.

The type strain, $\mathrm{SY01}^{\mathrm{T}}\left(=\mathrm{DSM} 23054^{\mathrm{T}}=\mathrm{KACC} 14895^{\mathrm{T}}\right)$, was isolated from tidal flat sediment from Sacheon Bay in South Korea. The G+C content of the genomic DNA of the type strain is $56.1 \mathrm{~mol} \%$.

\section{Acknowledgements}

This study was supported by grants from NG Biogreen 21 (SSAC, grant \#: PJ008109) from RDA, Korea.

\section{References}

Akaracharanya, A., Lorliam, W., Tanasupawat, S., Lee, K. C. \& Lee, J.-S. (2009). Paenibacillus cellulositrophicus sp. nov., a cellulolytic bacterium from Thai soil. Int J Syst Evol Microbiol 59, 2680-2684.

Ash, C., Priest, F. G. \& Collins, M. D. (1993). Molecular identification of rRNA group 3 bacilli (Ash, Farrow, Wallbanks and Collins) using a PCR probe test. Proposal for the creation of a new genus Paenibacillus. Antonie van Leeuwenhoek 64, 253-260.

Aÿ, J., Götz, F., Borriss, R. \& Heinemann, U. (1998). Structure and function of the Bacillus hybrid enzyme GluXyn-1: native-like jellyroll fold preserved after insertion of autonomous globular domain. Proc Natl Acad Sci U S A 95, 6613-6618.

Beneduzi, A., Costa, P. B., Parma, M., Melo, I. S., BodaneseZanettini, M. H. \& Passaglia, L. M. P. (2010). Paenibacillus riograndensis sp. nov., a nitrogen-fixing species isolated from the rhizosphere of Triticum aestivum. Int J Syst Evol Microbiol 60, 128133.

Chun, J., Lee, J.-H., Jung, Y., Kim, M., Kim, S., Kim, B. K. \& Lim, Y. W. (2007). EzTaxon: a web-based tool for the identification of prokaryotes based on $16 \mathrm{~S}$ ribosomal RNA gene sequences. Int J Syst Evol Microbiol 57, 2259-2261.

Felsenstein, J. (2002). PHYLIP (phylogeny inference package), version 3.6a. Distributed by the author. Department of Genome Sciences, University of Washington, Seattle, USA.

Hespell, R. B. (1996). Fermentation of xylan, corn fiber, or sugars to acetoin and butanediol by Bacillus polymyxa strains. Curr Microbiol 32, 291-296.

Kanzawa, Y., Harada, A., Takeuchi, M., Yokota, A. \& Harada, T. (1995). Bacillus curdlanolyticus sp. nov. and Bacillus kobensis sp. nov., which hydrolyze resistant curdlan. Int J Syst Bacteriol 45, 515-521.

Khianngam, S., Tanasupawat, S., Lee, J.-S., Lee, K. C. \& Akaracharanya, A. (2009a). Paenibacillus siamensis sp. nov., Paenibacillus septentrionalis sp. nov. and Paenibacillus montaniterrae sp. nov., xylanase-producing bacteria from Thai soils. Int J Syst Evol Microbiol 59, 130-134.

Khianngam, S., Akaracharanya, A., Tanasupawat, S., Lee, K. C. \& Lee, J.-S. (2009b). Paenibacillus thailandensis sp. nov. and Paenibacillus nanensis sp. nov., xylanase-producing bacteria isolated from soil. Int $J$ Syst Evol Microbiol 59, 564-568.

Kimura, M. (1980). A simple method for estimating evolutionary rates of base substitutions through comparative studies of nucleotide sequences. J Mol Evol 16, 111-120.

Komagata, K. \& Suzuki, K. (1987). Lipid and cell-wall analysis in bacterial systematics. Methods Microbiol 19, 161-207.

Lane, D. J. (1991). 16S/23S rRNA sequencing. In Nucleic Acid Techniques in Bacterial Systematics, pp. 115-175. Edited by E. Stackebrandt \& M. Goodfellow. Chichester: Wiley.

Lányí, B. (1987). Classical and rapid identification methods for medically important bacteria. Methods Microbiol 19, 1-67.

Lee, J. C. \& Yoon, K. H. (2008). Paenibacillus woosongensis sp. nov., a xylanolytic bacterium isolated from forest soil. Int $J$ Syst Evol Microbiol 58, 612-616.

Lee, H.-J., Shin, D.-J., Cho, N. C., Kim, H.-O., Shin, S.-Y., Im, S.-Y., Lee, H. B., Chum, S.-B. \& Bai, S. (2000). Cloning, expression and nucleotide sequences of two xylanase genes from Paenibacillus sp. Biotechnol Lett 22, 387-392.

Mesbah, M., Premachandran, U. \& Whitman, W. B. (1989). Precise measurement of the $\mathrm{G}+\mathrm{C}$ content of deoxyribonucleic acid by highperformance liquid chromatography. Int J Syst Bacteriol 39, 159167. 
Morales, P., Madarro, A., Flors, A., Sendra, J. M. \& Pérez-González, J. A. (1995). Purification and characterization of a xylanase and an arabinofuranosidase from Bacillus polymyxa. Enzyme Microb Technol 17, 424-429.

Nelson, D. M., Glawe, A. J., Labeda, D. P., Cann, I. K. O. \& Mackie, R. I. (2009). Paenibacillus tundrae sp. nov. and Paenibacillus xylanexedens sp. nov., psychrotolerant, xylan-degrading bacteria from Alaskan tundra. Int J Syst Evol Microbiol 59, 1708-1714.

Nielsen, P. \& Sorensen, J. (1997). Multi-target and mediumindependent fungal antagonisms by hydrolytic enzymes in Paenibacillus polymyxa and Bacillus pumilus strains from barley rhizosphere. FEMS Microbiol Ecol 22, 183-192.

Park, M. J., Kim, H. B., An, D. S., Yang, H. C., Oh, S. T., Chung, H. J. \& Yang, D. C. (2007). Paenibacillus soli sp. nov., a xylanolytic bacterium isolated from soil. Int J Syst Evol Microbiol 57, 146-150.

Park, D. S., Jeong, W. J., Lee, K. H., Oh, H. W., Kim, B. C., Bae, K. S. \& Park, H. Y. (2009). Paenibacillus pectinilyticus sp. nov., isolated from the gut of Diestrammena apicalis. Int J Syst Evol Microbiol 59, 13421347.

Rivas, R., Mateos, P. F., Martínez-Molina, E. \& Velázquez, E. (2005a). Paenibacillus xylanilyticus sp. nov., an airborne xylanolytic bacterium. Int J Syst Evol Microbiol 55, 405-408.

Rivas, R., Mateos, P. F., Martínez-Molina, E. \& Velázquez, E. (2005b). Paenibacillus phyllosphaerae sp. nov., a xylanolytic bacterium isolated from the phyllosphere of Phoenix dactylifera. Int J Syst Evol Microbiol 55, 743-746.

Rivas, R., Garcia-Fraile, P., Mateos, P. F., Martínez-Molina, E. \& Velázquez, E. (2006). Paenibacillus cellulosilyticus sp. nov., a cellulolytic and xylanolytic bacterium isolated from the bract phyllosphere of Phoenix dactylifera. Int J Syst Evol Microbiol 56, 2777-2781.

Saitou, N. \& Nei, M. (1987). The neighbor-joining method: a new method for reconstructing phylogenetic trees. Mol Biol Evol 4, 406425.

Sánchez, M. M., Fritze, D., Blanco, A., Spröer, C., Tindall, B. J., Schumann, P., Kroppenstedt, R. M., Diaz, P. \& Pastor, F. I. J. (2005). Paenibacillus barcinonensis sp. nov., a xylanase-producing bacterium isolated from a rice field in the Ebro River delta. Int J Syst Evol Microbiol 55, 935-939.

Shida, O., Takagi, H., Kadowaki, K., Nakamura, L. K. \& Komagata, K. (1997a). Transfer of Bacillus alginolyticus, Bacillus chondroitinus, Bacillus curdlanolyticus, Bacillus glucanolyticus, Bacillus kobensis, and Bacillus thiaminolyticus to the genus Paenibacillus and emended description of the genus Paenibacillus. Int J Syst Bacteriol 47, 289-298.

Shida, O., Takagi, H., Kadowaki, K., Nakamura, L. K. \& Komagata, K. (1997b). Emended description of Paenibacillus amylolyticus and description of Paenibacillus illinoisensis sp. nov. and Paenibacillus chibensis sp. nov. Int J Syst Bacteriol 47, 299-306.

Šmerda, J., Sedlácek, I., Pácová, Z., Durnová, E., Smísková, A. \& Havel, L. (2005). Paenibacillus mendelii sp. nov., from surfacesterilized seeds of Pisum sativum L. Int J Syst Evol Microbiol 55, 23512354.

Smibert, R. M. \& Krieg, N. R. (1994). Phenotypic characterization. In Methods for General and Molecular Bacteriology, pp. 607-654. Edited by P. Gerhardt, R. G. E. Murray, W. A. Wood \& N. R. Krieg. Washington, DC: American Society for Microbiology.

Tamura, K., Dudley, J., Nei, M. \& Kumar, S. (2007). MEgA4: Molecular evolutionary genetics analysis (MEGA) software version 4.0. Mol Biol Evol 24, 1596-1599.

Ten, L. N., Baek, S.-H., Im, W.-T., Lee, M., Oh, H. W. \& Lee, S.-T. (2006). Paenibacillus panacisoli sp. nov., a xylanolytic bacterium isolated from soil in a ginseng field in South Korea. Int J Syst Evol Microbiol 56, 2677-2681.

Thompson, J. D., Higgins, D. G. \& Gibson, T. J. (1994). CLUSTAL W: improving the sensitivity of progressive multiple sequence alignment through sequence weighting, position-specific gap penalties and weight matrix choice. Nucleic Acids Res 22, 4673-4680.

Timell, T. E. (1967). Recent progress in the chemistry of wood hemicelluloses. Wood Sci Technol 1, 45-70.

Uffen, R. L. (1997). Xylan degradation: a glimpse at microbial diversity. J Ind Microbiol Biotechnol 19, 1-6.

Valverde, A., Fterich, A., Mahdhi, M., Ramírez-Bahena, M.-H., Caviedes, M. A., Mars, M., Velázquez, E. \& Rodriguez-Llorente, I. D. (2010). Paenibacillus prosopidis sp. nov., isolated from the nodules of Prosopis farcta. Int J Syst Evol Microbiol 60, 2182-2186.

Vaz-Moreira, I., Faria, C., Nobre, M. F., Schumann, P., Nunes, O. C. \& Manaia, C. M. (2007). Paenibacillus humicus sp. nov., isolated from poultry litter compost. Int J Syst Evol Microbiol 57, 2267-2271.

Velázquez, E., de Miguel, T., Poza, M., Rivas, R., Rosselló-Mora, R. \& Villa, T. G. (2004). Paenibacillus favisporus sp. nov., a xylanolytic bacterium isolated from cow faeces. Int J Syst Evol Microbiol 54, 5964 .

Wang, M., Yang, M., Zhou, G., Luo, X., Zhang, L., Tang, Y. \& Fang, C. (2008). Paenibacillus tarimensis sp. nov., isolated from sand in Xinjiang, China. Int J Syst Evol Microbiol 58, 2081-2085.

Yoon, J. H., Seo, W. T., Shin, Y. K., Kho, Y. H., Kang, K. H. \& Park, Y. H. (2002). Paenibacillus chinjuensis sp. nov., a novel exopolysaccharideproducing bacterium. Int J Syst Evol Microbiol 52, 415-421.

Zamost, B. L., Nielsen, H. K. \& Starnes, R. L. (1991). Thermostable enzymes for industrial applications. J Ind Microbiol 8, 71-81. 